Thrice Nahum 3:8-10: MT, LXX, and 4Q385a 17 ii — New Proposals

1. Text

Nahum 3:8-10 is part of a larger poem addressed against Nineveh. ${ }^{1}$ In these three verses the past fate of No-Amon, which was thought to have been inconquerable, but nonetheless was taken, is set as a warning for Nineveh. Modern scholarship understands No, or No-Amon, as the Hebrew form of Egyptian niwt, "the city," or niwt Imn, "the city of Amon," a reference to Thebes which was captured by the Assyrians in 663 BCE. $^{2}$ In the Hellenistic period and later, however, the name No was rarely understood as referring to ancient Thebes. The letters נא were not recognized as a proper name at all (as in LXX Jer 26:25 = MT 46:25, and Nah 3:8), or they were simply transliterated, or interpreted as referring to Alexandria, perhaps because of the description of its relation to the rivers and the sea in Nah $3: 8 .^{3}$

${ }^{1}$ This delineation is based on the content describing No-Amon, and the preservation of the verses in 4Q385a. Other delineations are possible, e.g., Klaas Spronk, "Synchronic and Diachronic Approaches to the Book of Nahum," in Synchronic or Diachronic? A Debate on Method in Old Testament Exegesis (ed. Johannes C. de Moor; OTS 34; Leiden: Brill, 1995), 159-86 present a poetic structure of the book of Nahum, and considers Nah 3:7-9 and 10-12 to constitute a subcanto.

${ }^{2}$ For general discussions of Nah 3:8-10 and the name No-Amon see the commentaries, e.g., Klaas Spronk, Nahum (HCOT; Kampen: Kok, 1997) or Heinz-Josef Fabry, Nahum (HThKAT; Freiburg: Herder, 2006), as well as John R. Huddlestun, "Nahum, Nineveh, and the Nile: The Description of Thebes in Nahum 3:8-9," JNES 62 (2003): 97-110. J. Van Doorslaer, “No Amon," CBQ 11 (1949): 280-95 rejects the identification with Thebes, and proposes No-Amon was a precursor of Alexandria. CarlA. Keller, Nahoum, Habacuc, Sophonie (CAT 11b; Genève: Labor et Fides, 1990), 130, suggests that No or No-Amon is not a reference to a specific Egyptian city, but to Egypt in general.

${ }^{3}$ For a comprehensive overview, cf. Arie van der Kooij, "The City of Alexandria and the Ancient Versions of the Hebrew Bible," JNSL 25 (1999): 137-49. 


\subsection{LXX and MT}

The failure to recognize the proper names No and Put in Nah 3:8-9 is given as the reason for the strange and partly unintelligible LXX translations of those verses. ${ }^{4}$ One may compare the MT and the LXX:

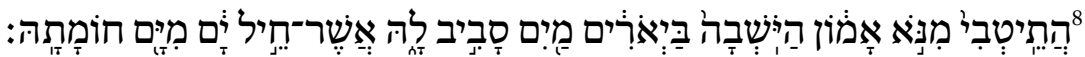

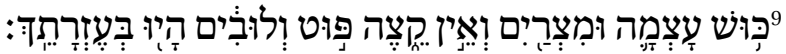

\footnotetext{
${ }^{8}$ Are you better than No-Amon, dwelling at the rivers? Waters were surrounding her, whose rampart was the sea, of the sea her wall.

${ }^{9} \mathrm{Cush}$ was her strength and Egypt, and there was no end, Put and Lubim were your helpers. $\left(\operatorname{Spronk}^{5}\right)$

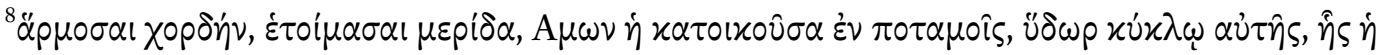

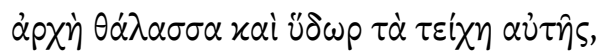

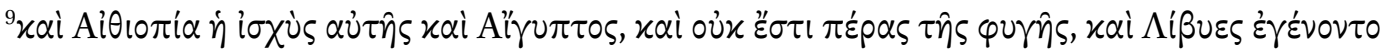

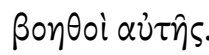

${ }^{8}$ Tune a chord; prepare a portion, $\mathrm{O}$ Amon who dwells in rivers; water is around her, whose dominion is the sea, and her walls are water, ${ }^{9}$ and her strength is Ethiopia and Egypt—and there is no end to flight! Even the Libyans have become her helpers. (NETS)

${ }^{4}$ On the LXX translation, cf. especially M. Harl et al., eds., Les Douzes Prophètes: Joël, Abdiou, Jonas, Naoum, Ambakoum, Sophonie (La Bible d'Alexandrie 23.4-9; Paris: Cerf, 1999; = BdA 23.4-9), with references to earlier discussions, and Fabry, Nahum.

${ }^{5}$ Translation adopted from Spronk, "Synchronic and Diachronic," 175. 


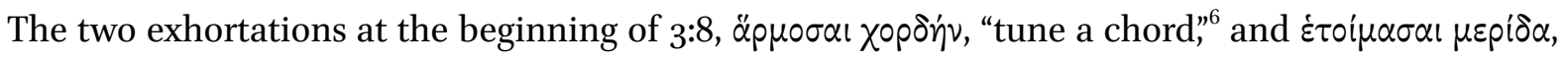
"prepare a portion,"7 are generally taken as two different interpretations of the Hebrew התיטבי מנא, or a similar Hebrew wording (4QpNah 3-4 iii 8 reads התיטיבי מני ). Because מנא was not understood

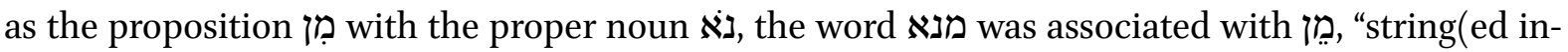
strument)," or מָזָה ,portion." In both interpretations the preceding verbal form was not construed as the interrogative particle הith an imperfect form, but rather understood as an imperative. These two clauses would then be an example of a double translation, with one of the translations added by a later reviser, and included by a subsequent copyist in the text. ${ }^{8}$ However, neither individually, nor together, do these two exhortations provide a meaningful reading within the context of Nah $3 \cdot{ }^{9}$ In the remainder of the verse, the Greek seems closer to the Masoretic consonantal text, but sometimes with a different interpretation of the wordd. For example, $\alpha p \chi \dot{\eta}$, whether understood as "dominion" or "beginning," is not a translation of Hebrew חיל, "rampart," but either a rendering of חַיִיל, "strength, power"10 or a translation based on the association with החי, "to begin." Also, the second part of this verse has several small differences between the Greek and the Masoretic text, where the Greek seems to corresponds more closely to the Hebrew preserved in the quotation of the Nahum pesher (4Q169 3-4 iii 9) which reads אשר חילה ים ומים חמותיה.12

\footnotetext{
${ }^{6}$ Huddlestun, "Nahum, Nineveh," 97 n. 1, renders “arrange the entrails."

${ }^{7}$ Huddlestun, ibid., renders "Prepare the (sacrificial?) portions."

${ }^{8}$ On "double translations," and the different definitions of scholars, cf. Mirjam van der VormCroughs, The Old Greek of Isaiah: An Analysis of Its Pluses and Minuses (SBLSCS 61; Atlanta: Society of Biblical Literature, 2014).
}

${ }^{9} \mathrm{BdA}$ 23.4-9, 225: "Ces deux injonctions, qui se comprennent au mieux comme renvoyant au travail d'un géomètre, n'ont aucun rapport avec le contexte."

${ }^{10} \mathrm{BdA} 23 \cdot 4-9,225$.

"Anthony Gelston, The Twelve Minor Prophets (BHQ 13; Stuttgart: Deutsche Bibelgesellschaft, 2011), $113^{*}$ and Fabry, Nahum, 202.

${ }^{12}$ Beate Ego et al., Minor Prophets (Biblia Qumranica 3B; Brill: Leiden, 2005), 121 fails to indicate the 
In verse 9 the major difference between the Masoretic text and the LXX is in the middle of

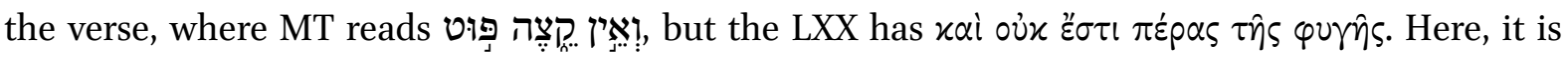
conventionally argued, the LXX translator either did not recognize the proper name פוט, and interpreted it as פלט, פוט in the Vorlage as פלט in alternative possible misreading would be the graphic confusion between פוס and Here, again, the resulting Greek text hardly makes sense within the context. The verse refers to Amon's strength, being supported by Ethiopia, Egypt, and the Libya. It is therefore not clear how the reference to limitless flight would fit in this depiction. ${ }^{14}$ The variant with respect to person at the end of the verse (MT: your helpers; LXX: her helpers) is difficult to solve. Within the broader context of the MT, the second person creates a contrast between Ethiopia and Egypt who support Thebes, versus Put and the Libyans who supported Nineveh. The reading of the LXX is easier and has been accepted by many modern commentators and translations (e.g., NRSV: "Put and the Libyans were her helpers"). The LXX of verse 10 has no major variants vis-à-vis the MT. The main difference is that the LXX does not construe the text to depict in past tense the fate of the inhabitants of Thebes, but rather as a future description. Such an eschatological interpretation may have been prompted by the lack of understanding the historical reference in the verses, but it also aligns more generally with a tendency towards reinterpretation and even Fortschreibung in LXX Nahum. ${ }^{15}$

1.2. $4 \mathrm{Q} 385$ a 17 ii and MT

variants concerning the conjunction before מים and the variant relating to the number of חומה.

${ }^{13}$ E.g., BdA 23.4-9, 226; BHQ crit. app.; Fabry, Nahum, 202.

${ }^{14} \mathrm{BdA} 23 \cdot 4-9,226$ gives a positive interpretation of the Greek: there is ample space for military withdrawal.

${ }^{15}$ Heinz-Josef Fabry, “The Lord Over Mighty Waters" in Translating a Translation; the LXX and Its Modern Translations in the Context of Early Judaism (ed. Hans Ausloos et al.; BETL 213; Leuven: Peeters, 2008), 151-65, esp. 164-65; BdA 23.4-9, 186-87. 
The text of $4 Q_{3} 85$ a 17 ii is only partially preserved, and some broken letters are difficult to read. ${ }^{16}$ Moreover, given the attested differences between MT and this text, reconstructions on the basis of MT are uncertain. I propose to read the text of the fragment as follows: ${ }^{17}$

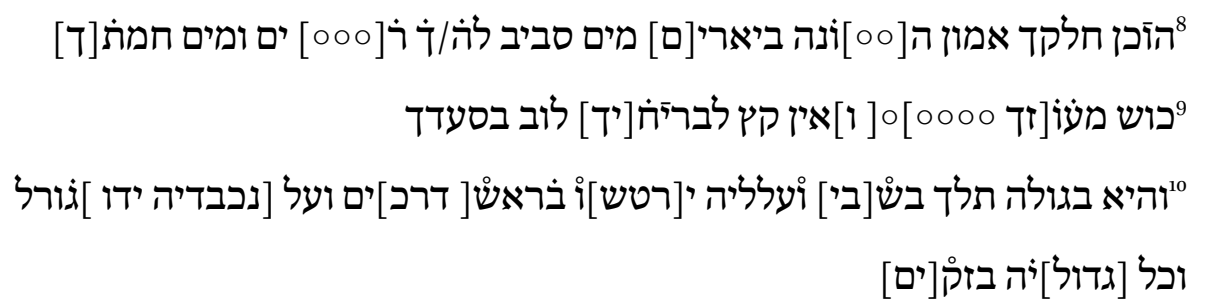

${ }^{16}$ The text was first edited by Devorah Dimant, "A Quotation from Nahum 3:8-10 in the Fragment 4Q385 6 from Qumran," in the Bible in the Light of Its Interpreters: Sara Kamin Memorial Volume (ed. Sara Japhet; Jerusalem: Magnes, 1995) 31-37 (Hebrew), who also edited the text in her Parabiblical Texts, Part 4: Pseudo-Prophetic Texts (DJD 30; Oxford: Clarendon, 2001), 155-59 (= DJD 30). Elisha Qimron, The Dead Sea Scrolls: The Hebrew Writings, Volume Two (Jerusalem: Yah Ben-Zvi, 2013), 89, follows Dimant. Monica Brady, "Prophetic Traditions at Qumran: A Study of 4Q383-391" (PhD diss., University of Notre Dame 2000), 217-27 presents a text which adopts some of Strugnell's original readings, which also are represented as readings of the not yet combined fragments in Ben Zion Wacholder and Martin G. Abegg, A Preliminary Edition of the Unpublished Dead Sea Scrolls: The Hebrew and Aramaic Texts from Cave Four, Fascicle Three, based on a reconstruction of the original transcriptions of Jozef T. Milik and John Strugnell (Washington, D.C.: Biblical Archaeologicl Society, 1995), 232, 233, 238, 239, 240. Kipp Davis, The Cave 4 Apocryphon of Jeremiah and the Qumran Jeremianic Tradition: Prophetic Persona and the Construction of Community Identity (STDJ 111; Leiden: Brill, 2014), 127-32 presents an independent transcription, but his translation and notes do not always correspond to his transcription. For Davis's suggestion of a "liturgical" function of the unit, cf. ibid., 168-69.

${ }^{17}$ This alignment follows the verses of Nah 3:8-10, not the lines of the fragment. My reading differs from Strugnell's only in a few cases. 
${ }^{8}$ Your portion is determined, O Amon, who [...] at the rivers; water is around her/you, [your ...] is the sea, and [your] walls are water,

${ }^{9} \mathrm{Cush}$ is [your] stren[gth ..., and] there is no limit to [your] bars; Libya is your helper.

${ }^{10}$ But she will go into exile, in capti[vity,] and her children will be [dashed in pieces] at the head [of the street]s. And for [her nobles they will cast] the lot, and all her [great men] in chain[s.]

Even though almost half of the words are different or display variants, the correspondence with Nah 3:8-10 seems assured, and scholars have understood this text against that of the Masoretic text.

For the variant of the first two words, היכן/הוכץ ${ }^{18}$ wלקך which differ entirely from MT's

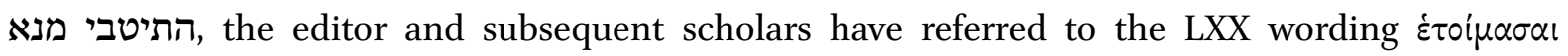
$\mu \varepsilon p i \delta \alpha .^{19}$ They seem to argue that חלק, which itself is an interpretation of a text like that of MT (Kister proposes התטיבי מני rather than התיטבי מנא). In that case the 4Q385a text, regardless whether one reads הוכן or היכן with חלקד, would represent either a corruption, or a subsequent scribal interpretation of the Hebrew reading הכיני חלק. In other words: LXX and $4 \mathrm{Q}_{3} 85$ a would be witnesses to a second, interpretive, synonymous reading of התיטבי מנא, a translation of which could have been added initially as a gloss to a Greek translation and later on included in the text. Though it is plausible that the LXX preserves a doublet, and that there is a connection with the $4 \mathrm{Q}_{3} 85 \mathrm{a}$ text, a more specific explanation needs to take into account the textual profile and literary character of the Nahum verses in 4Q385a.

\footnotetext{
${ }^{18}$ Palaeographically, both היכן and are possible. For lexical reasons and because of the content and the correspondence with LXX, I prefer הוכן.

${ }^{19}$ See Dimant's both editions, as well as Menahem Kister, "A Common Heritage: Biblical Interpretation at Qumran and Its Implications," in Biblical Perspectives: Early Use and Interpretation of the Bible in Light of the Dead Sea Scrolls (ed. Michael E. Stone and Esther G. Chazon; STDJ 28; Leiden: Brill, 1998), 101-11, at 107-8 n. 26, and Fabry, Nahum, 201-2.
} 
Characteristic for the $4 \mathrm{Q}_{3} 85$ a version of Nah 3:8-10 is the large amount of synonymous readings. The first two words, just discussed, have been explained as an attempt to substitute an

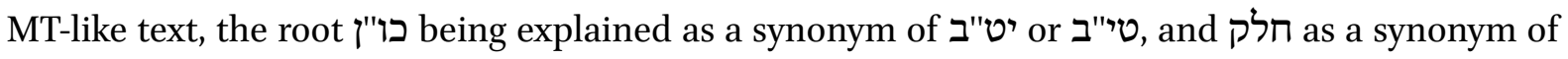

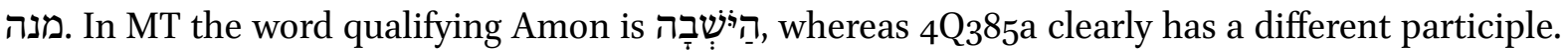

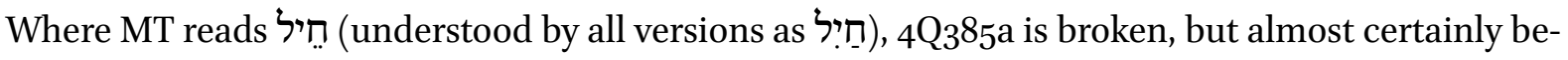
gins with a reš rather than a het..$^{20}$ In verse 9, in stead of שְָָׁמָה, the broken text probably read the

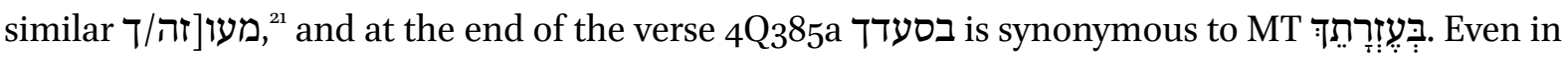
verse 10, which is badly preserved, the word corresponding to חוצוצת ends in and hence is different, possibly the synonymous דרכים. Some of those synonymous readings might perhaps be explained as substitutions of a difficult Masoretic text by 4Q385a, for example הוכן as a rendering of

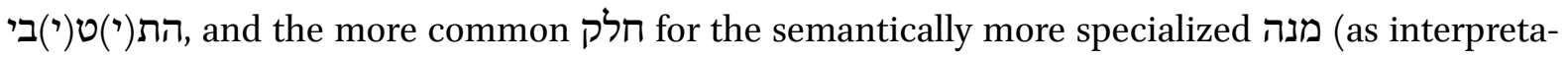
tion of מני or מנא by another participle would require another explanation, and, given its distribution in the preserved texts, the noun סעד would be less common than עזרה. While some synonyms plausibly are interpretive, others could be simply synonymous variants, a phenomenon which is more often attested in parallel passages, as the result of separate transmissions of a text.

One major variant which does not seem to be a synonymous variant is the broken phrase

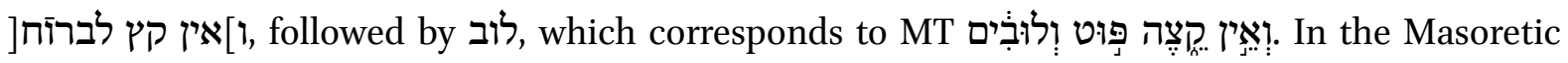

\footnotetext{
${ }^{20}$ Thus only Davis, Cave 4 Apocryphon, 127, 130.

${ }^{21}$ Dimant and Qimron read מצרי]ם, of which șade is impossible. Indeed reš is optically suggested by the slightly offset join of the fragments. In the Preliminary Concordance Strugnell recorded מעב] (thus also Davis) which Wacholder and Abegg supplemented to מעב]ר לים. However, as indicated by Dimant and Brady, Strugnell later considered מעו]ה. The supposed faint basestroke, which would suggest bet is not on the photographs. Instead, it does have at the very end of the baseline of 17a bottom a dark spot, which might be ink of a next letter, in which case one should

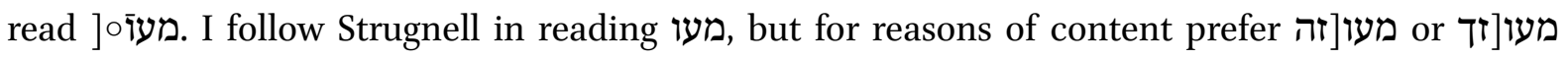
above מעו[נה.
} 


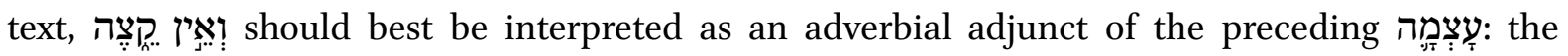
אֵין קָץ strength of Kush and Egypt was boundless (compare Isa 9:6; Eccl 12:12, but in both cases without conjunction). Put and Lubim belong to the following next verse line. In $4 \mathrm{Q}_{3} 85 \mathrm{a}$ is complemented by $ל$ and a broken word which should most likely be constructed to be a noun. On

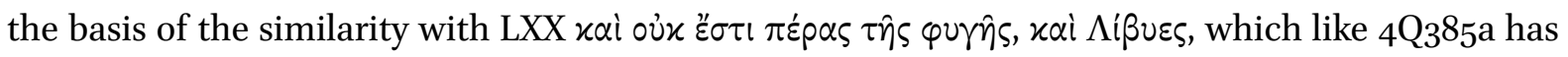
a complement to "end", and lacks the MT name פוט, one could consider to read a form of the root בר"ח, "to flee." This might be an infinitive ברוח, but more likely a verbal noun בריחה, "flight," or a the plural noun בריחים, "fugitives." As stated above in 1.1., a reference to limitless flight does not seem fitting in a description of strength. Dimant is not influenced by the LXX reading, and instead provides a reconstruction that fits better in the context, and is based on Nah 3:13, בריח]יד, "your bars." Taken synechdochic, the "bars" refer to protected gates, ${ }^{22}$ while the motif of Thebes' endless gates is already expressed in Homer, Il. 9.381-383 which hyperbolically refers to the hundred gates of Thebes. While a reconstructed form of בריחה (cf. LXX $\varphi v \gamma \eta \dot{)}$ could perhaps be explained as a misreading of פוט, a reading of a plural of בריח, "bars," cannot be connected easily to the MT reading. Rather, one would have a double textual tradition, of which neither one can be explained as secondary to the other.

In the MT and $4 \mathrm{Q}_{3} 85 \mathrm{a}$ there is some uncertainty about second and third person forms. In the MT text, the initial second person verbal form הִתִיטְטִבי is addressed to Nineveh, while the description of Thebes uses third person forms. The only problem in MT is the second person suffix in

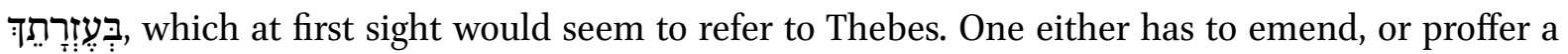
another interpretation. The situation in $4 \mathrm{Q}_{3} 85$ a should be easier, since the verses are disscolved from their Nineveh setting, and they only address Amon. This reading is confirmed by the second person suffixes in בסעדך and refer to Amon, while second person forms might also be reconstructed in the lacunae. The only inconsistency is the reading לה, which, however, given the appearance of the remaining traces may have been corrected to לך

\footnotetext{
${ }^{22}$ Brady, "Prophetic Traditions at Qumran," 218, even translates "gates."

${ }^{23}$ Strugnell read לה, but Dimant proposed לך. The slightly curved (not straight as Dimant claims)
} 
corresponding to Nah 3:10, the text has the same third person forms as Nahum. This shift from second to third person results in a contrast, which either opposes the second person addressee (Amon) of verse 8-9, to a different third person party (either Libya, because it is the last mentioned name in the preceding text, or an unspecified party) in verse 10, or, alternatively, marks, for example, a shift from present to future.

\subsection{Q385a 17 ii and LXX}

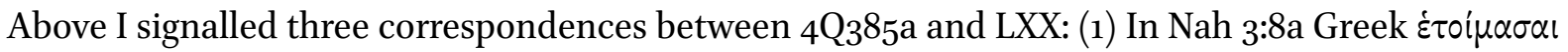

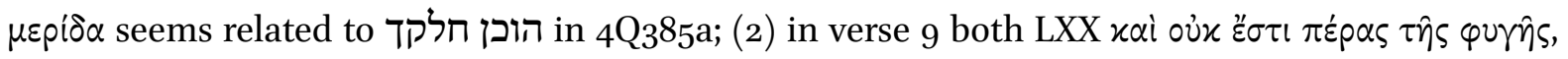

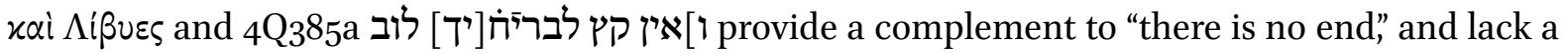
correspondence to MT פוט; and (3) both LXX and 4Q385a construe vs. 10 as a future event. One may perhaps add another possible correspondence, namely (4) that $\dot{\alpha} p X \dot{\eta}$ in $\hat{\eta} \varsigma \dot{\eta} \dot{\alpha} p \times \dot{\eta} \theta \dot{\alpha} \lambda \alpha \sigma \sigma \alpha$

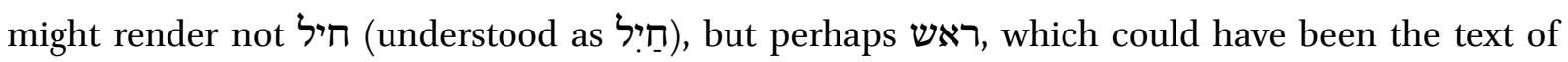
$4 Q_{3} 85$ a of which now only resh remains.

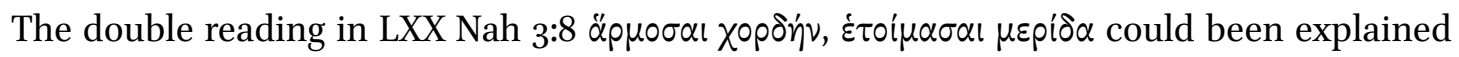
as a double translation of one and the same Hebrew phrase, התיטבי מנא. However, the frequent

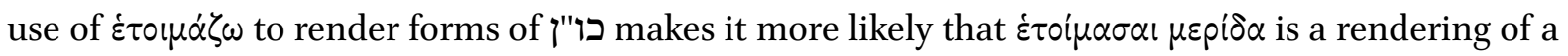
phrase similar to that in $4 Q_{3} 85$ a. The easiest assumption is that of a Hebrew הכן חלק, with a defectively written hof'al (הֶכַ; cf. Nah 2:6, a probably similar case where the translator interpreted the

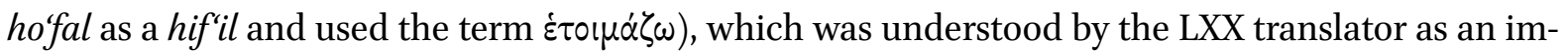
perative hif'il (הכָָ).

The correspondence between LXX and 4Q385a in verse 9, against the MT, can hardly be explained as arriving from two independent misreadings or interpretations of פלט as. פלט It is difficult to attach sense to the LXX reading, but the $4 Q_{3} 85$ a reading (partly reconstructed) fits very well in the context. Moreover, the LXX reading can most easily be explained as resulting from the con-

right downstroke may suggest final kap rather than he, but there are remnants of a left downstroke. Given the ambiguity of the traces, it is possible that either letter was transformed into the other. 


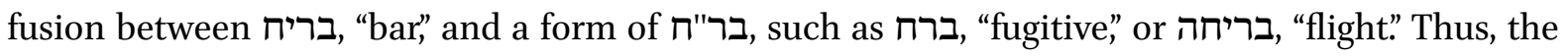
LXX Vorlage may have had בריחיה, "her bars," or, if one follows the majority Greek reading which

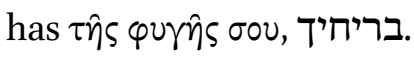

In sum, on the basis of this evidence one can assume that the LXX was aware of the double reading of the beginning of verse 8 , and translated a Hebrew text that had the variant reading of $4 Q_{3} 85$ a in the middle of verse 9 . Both variants which are attested in $4 Q_{3} 85$ a may have been part of a scroll which contained the entire book of Nahum.

1.4. Conclusion on the relation between the witnesses

For the words No-Amon we can assume that the MT goes back to a text from the period in which No was still known to refer to Thebes. The $4 \mathrm{Q}_{3} 85$ a fragment and the LXX show two attempts to understand the word differently. This does not of necessity imply that overall the MT of these three verses transmits the most original text. The synonyms in $4 Q_{3} 85$ a cannot be explained as interpretations or misunderstandings of an unintelligible MT text, and should be considered as synonymous variants. It is plausible that the $4 \mathrm{Q}_{3} 85$ a variant in the middle of verse 9 preserves an old form of the text. Most importantly, the LXX used a Hebrew text that was not identical to either MT or 4Q385am but included variants known from 4Q385a.

\section{Literary Form}

Because of the focus on the textual relation between Nah 3:8-10 and its so-called reworking in $4 \mathrm{Q}_{3} 85 \mathrm{a}$, less attention has been paid to the literary form of these verses in their $4 \mathrm{Q}_{3} 85_{5} \mathrm{a}$ form. Jassen claims that by extracting these verses from their Nahum and Nineveh context and placing them in a different literary work, within an eschatological context, the prophecy is recontextualized. ${ }^{24}$ This would also have been effected by the textual change of third person forms to second person ones: the prophecy is reapplied to Egypt in the author's own time. However, the new

\footnotetext{
${ }^{24}$ Alex P. Jassen, Mediating the Divine: Prophecy and Revelation in the Dead Sea Scrolls and Second Temple Judaism (STDJ 68; Leiden: Brill, 2007), 228-30.
} 
meaning of the text is not only given by its new literary context, but even more so by the specific textual changes in the text. ${ }^{25}$

2.1. "Your portion is established, O Amon"

The recontextualization of the text is reflected in the first two verbs. Nineveh is not addressed anymore, but Amon is now the addressee. However, because חלקד, "your portion," is considered to reflect an incorrect understanding of MT מנה as, "portion," little attention has been given to its meaning in the present text. Dimant does not read at the beginning הוכן חלקך אמון, but אמון, "where is your portion, O Amon?"-but without explaining what this question does in the text. It is preferable to depart from the reading הוכן. Perhaps the text read originally הוכן חלק אמון, "established is the portion of Amon", which subsequently was changed into the text found in 4Q385a, "etablished is your portion, O Amon." Though כלק חלק, the wide range of meanings of כו"ץ, permits one to consider different meanings of the collocation.

Since כו' מו" hif'il can mean "establish," or "prepare," and חלק may refer in bonam partem to one's allotted property defined by boundaries, the expression "your (allotted) property has been established" could introduce the subsequent description in verses 8-9 of Amon's geographical (and strategic-political) setting. Alternatively, when we take כו" hif'il as "determine" and חלק in the specific meaning of "allotted fate," then we may understand the expression in malam partem as "your fate has been determined" and anticipating verse 10. Here, the problem signalled above returns: does the shift from second to third person forms in verse 10, introduced by והיא, "but she," create a contrast between Amon which is firmly secured, and another city that will be conquered?

But what was Amon? In later times, the geographical description of Nah 3:8 resulted in the identification of No or No-Amon with Alexandria, and it is possible that the $4 \mathrm{Q}_{3} 85$ a text already associated Amon with Alexandria, or, more generally, with Ptolemaic Egypt. The question is then whether the unit envisages the down-fall of Alexandria, or, in contrast, that of another city.

\footnotetext{
${ }^{25}$ The proposals in this paper are different from those I presented in an earlier article, "Jeremiah's Scriptures in the Dead Sea Scrolls and the Growth of a Tradition."
} 
2.2. The $4 \mathrm{Q}_{3} 85$ a Amon Unit within $4 \mathrm{Q}_{3} 85$ a Apocryphon of Jeremiah $\mathrm{C}^{\mathrm{a}}$

Because of the fragmentary nature of both the fragment and the manuscript it is hard to determine where and how the fragment relates to the manuscript of text as a whole. From a material point of view the sequence $4 Q_{3} 85^{a}{ }^{1-16-17}$ as representing two subsequent layers of the scroll is established by the discovery of two fragments still attached in a pile ${ }^{26}$ and the correspondence of shape, and juxtaposition on the older photographs, of other fragments. ${ }^{27}$ From this material point of view, $4 \mathrm{Q} 385 \mathrm{a} 15 \mathrm{ii}+16+17$ i constitute the remains of the column preceding frag. $17 \mathrm{ii}^{28}$ Some correspondences of shape and juxtapositions of fragments on the earliest photograph (PAM 41.503) suggest but do not prove that the column with 4Q385a 18 immediately followed frag. $17 \mathrm{ii}$.

The Amon unit may therefore be read as part of the conclusion of a longer oracular section that extends from at least frag. $15 \mathrm{i}$ to frag. $17 \mathrm{ii}$, and just before the narrative account of Jeremiah's speeches to the exiles in frag. $18 \mathrm{i}$-ii. This oracular section is highly damaged, and even the reference to "hanging on a tree" in $4 Q_{3} 85$ a 15 i and the joint text of $4 Q_{3} 85$ a 15 ii $+16+17 \mathrm{i}^{29}$ including a phrase "I will dispossess Greece ${ }^{\text {"30 }}$ are too fragmentary to interpret with much confidence. ${ }^{31}$ At best,

\footnotetext{
${ }^{26}$ The bottom piece of $4 Q_{3} 8517$ frag. a (containing the word לוב) is still on top of the corresponding bottom part of frag. 15 (lines $5^{-6}$ ) (and on top of frag. 14 as the third fragment in the pile) in PAM 40.975. Compare the subsequent separation of the fragments in PAM 41.642, 41.791, and 41.851, establishing clearly that frags. 15 and 17a belonged to two subsequent revolutions of the scroll. Cf. Davis, The Cave 4 Apocryphon of Jeremiah, 79, fig. 2.2.

${ }^{27} \mathrm{Cf}$. the juxtaposition on PAM 41.208 of $4 \mathrm{Q}_{3} 85 \mathrm{a} 16 \mathrm{~b}$ and $17 \mathrm{~d}$, and compare the damage patterns.

${ }^{28}$ Qimron, The Dead Sea Scrolls: The Hebrew Writings, Volume Two, 89, 101-2 completely disregards this material evidence by assigning frag. 17 to "The words of Ezekiel" and the other fragments to "The words of Jeremiah."

${ }^{29}$ For the alignment of the fragments see Davis, The Cave 4 Apocryphon ofJeremiah, 124-25.

${ }^{30}$ One should reject Qimron's reading יהץ יון (The Dead Sea Scrolls: The Hebrew Writings, Volume Two, 102).
} 
one may conceive on the basis of words and phrases that the oracle in $15 \mathrm{ii}+16+17$ i contrasts "his people" to Greece and the Lebanon, concluding that some (of his people?) will search YHWH. After a lost part, the next fragment resumes in 17 ii with a reference to the garden of life (as abode of those who sought $\mathrm{YHWH}$ ?). It is after that reference, in a new paragraph that the Amon unit begins. Due to the separation of the Amon unit from the preceding text, it is not clear whether this unit concludes a narrative oracular sequence, or should be read as an independent unit. ${ }^{32}$ Likewise, it is not clear how the Amon unit relates to the immediately following report on Jeremiah and the exiles. One might therefore also hypothesize that this scroll brings together disparate materials that are somehow related to Jeremiah.

Though it is virtually impossible to connect the Amon unit to its direct literary context, the composition as reflected in this scroll provides a larger context. It refers in $4 \mathrm{Q}_{3} 85 \mathrm{a} 18 \mathrm{i}$-ii to the land of Jerusalem and the two locations of exile, Babylon and Egypt. In its apocalyptic overview of Second Temple history the text moves quickly from the period of exile to that of Antiochus IV ("a king of the nations, a blasphemer and a doer of evil"), his conquest of Egypt, and the subsequent turmoils and different priests in Israel, until the rise of the reform movement. ${ }^{33}$ The text is concerned with the exile brought about by the arrogant Babylonians, the subsequent oppression by the evil Seleucids, and the behaviour of Israel under those circumstances. The text does not, however, display in its preserved parts any negative attitude towards Egypt. In fact, criticism of Egypt is almost nonexistent in second-century BCE Jewish literature at large. From that broad perspective,

\footnotetext{
${ }^{31}$ One should question reconstructions on the basis of biblical locutions. Moreover, some words and phrases are ambiguous. In frag. 16 I would prefer to interpret בכן as "therefore," rather than "among you."

${ }^{32}$ Dimant, DJD 30, 158 claims positively that in spite of the new paragraph, "the juxtaposition of the two paragraphs suggests that they both belong to a single context."

${ }^{33} \mathrm{~A}$ composite text of three columns can be restored on the basis of $4 \mathrm{Q}_{3} 87$ 1, 2 i-iii, and 3 , supplemented by the text of 4Q385a 3a, 3b, 3c, 4, 5; 4Q388a 3, 7 ii; 4Q389 6, 7, 8; 4Q389 8 ii. Cf. Davis, The Cave 4 Apocryphon of Jeremiah, 144-56.
} 
a diatribe against Amon, if understood as Egypt or Alexandria, would come as a surprise. Instead, the observed contrast within the Amon unit between second and third person forms, could suggest here a contrast between Amon for whom a safe portion has been determined, and the other party ("but she") who will be taken captive. Syntactically, "but she" could refer back to the preceding Libya, but the possible historical context of the composition suggests another possibility.

\section{History}

While scholars agree that the Nah 3:8-10 refers to the defeat and plunder of Thebes in 663 BCE, it is less clear whether one should interpret its variant form in $4 \mathrm{Q}_{3} 85 \mathrm{a}$ as a reference to a historical event. The historical apocalypse in the Apocryphon of Jeremiah C runs till the end of the second century BCE. Unfortunately, the wording of the events after the Antiochean crisis is broken, but the text mentions that "three priests who will not walk in the ways of the former priests will be called by the name of the God of Israel" (4Q387 $34-5$ ) which could refer to the first three Hasmonean priest-rulers, Jonathan, Simeon, and John Hyrcanus. ${ }^{34}$ It is in that generation that Israel "will be rent asunder in that generation, each man fighting against his neighbour over the law and over the covenant" (4Q387 37-8; cf. Jub. 23:19), suggesting that this part of the composition derives from the late second century.

It is not clear, however, how the subsequent sections in the $4 \mathrm{Q}_{3} 85$ a scroll should be read, as other vaticinia ex eventu, be it referring to an earlier period, or as eschatological oracles..$^{35}$ The editor suggested, be it tentatively, that $4 Q_{3} 85$ a 16 and the "prophecy against Egypt" in $4 Q_{3} 85$ a 17 could have been part of an "eschatological prophecy about the Ptolemaic kingdom," reflecting the events connected with the invasions of Egypt by Antiochus IV in 170-169 BCE. ${ }^{36}$ The editor, however, does not spell out which historical events correspond to which phrases in the text. While Anti-

\footnotetext{
${ }^{34}$ Cf. D. Dimant, "Pseudo-Ezekiel and the Apocryphon of Jeremiah C in Perspective," RevQ 25/97 (2011): 17-39, at 34 n. 67 .

${ }^{35}$ Compare Dimant, DJD 30, 154 “completely fictional or ... a forecast patterned after real events." ${ }^{36}$ Ibid., 158.
} 
ochus IV in his two invasions of Egypt in 170-168 BCE twice wanted to conquer Alexandria, he did not succeed, the second time due to the Roman intervention led by Popilius Laenas. It was after this event that, according to 2 Macc 5:11-14 he took Jerusalem captive, slaughtered many, and took many others away as slaves. If we read the Amon unit in its $4 \mathrm{Q}_{3} 85 \mathrm{a}$ wording and in a second-century BCE context, then, rather than being a diatribe against Egypt, it should be interpreted as an ex eventu prophecy contrasting the rescue of Alexandria with the capture of Jerusalem during 170-167 BCE.

Why would an author, editor, or scribe incorporate a older prophecy that seemed to predict the calamitous events of 167 BCE in this Apocryphon of Jeremiah? Surely, the organization of the $4 \mathrm{Q}_{3} 85$ a text, possibly a Sammelhandschrift, ${ }^{37}$ is not chronological, and this unit, which is followed by the report of Jeremiah's speeches, is not the climax of the text. Rather, its position at the end of the oracles, may be due to its distinct and separate character, which perhaps, in some way, was thought to be connected to the earlier "Jeremianic" oracles.

\section{Conclusion}

The trajectory from text through literary form to history is fitting in a contribution to John Collins, who is exegete, literary critic, and historian (and so much more) at the same time, and always has encouraged scholars to deal with all those different aspects of the field. As a journal editor, I have always immensely benefited from John's multiple reviews of articles which I sent him. Not only would John promptly response with comments, corrections, or suggestions. But also would he display a perceptive view on what would be important for the progress of scholarship. Sometimes he would express hesitation or even doubt about the validity of a proposal, but nonetheless encourage publishing the paper, because of a different perspective or argument which would stimulate discussion. It is therefore that I present here my new proposals..$^{38}$

\footnotetext{
${ }^{37}$ As suggested in Tigchelaar, "Jeremiah's Scriptures."

${ }^{38}$ I thank Kipp Davis and Årstein Justnes for organizing two enjoyable days of reading the $4 \mathrm{Q}_{3} 85 \mathrm{a}$ fragments in September 2013 in Kristiansand, Norway. Parts of the first section of this paper were
} 
presented at the conference Textual Unities (Yale University, October 2013), the symposium The Septuagint in Dialogue (Leuven, October 2013), the conference Jeremiah's Scriptures: Production, Reception, Interaction, and Transformation (Monte Verità, Ascona, June 2014), and the 222nd meeting of the Oudtestamentisch Werkgezelschap (Utrecht, January 2016). I thank the organizers of these events for their invitations. In addition I am indebted to Bob Becking, Shira Golani, Bärry Hartog, and Arie van der Kooij for suggestions, and Marieke Dhont for her help with Septuagintal matters. 